be cxeecdingly useful both to nurserymen and inspectors, and would certainly help to put these two parties into more sympathetic relations in the search for their common enemies.

Alas! after having drawn up an outline of what I had to say, a copy of the programme reached me which showed that practically all of my thoughts and queries were already provided for, and many more besides. We will, thereforc, do well to proceed with the business of the Association at this, its Tenth Annual Mecting, which will, let us hope, be one of great pleasure and profit.

\title{
SOME RECENT NEW IMPORTATIONS
}

By C. I. MarlatT, Bureau of Entomology, U. S. Department of Agriculture

It is not necessary nor is it possible to report fully on importations of new pests during the last few years. To emphasize the need of protection at the carliest possible moment, a few recent records, or recent destructive work of older importations, may be noted.

\section{CONDITION OF IMPORTED NURSERY STOCK, 1910-1911}

Fewer brown-tail moth nests were received on imported stock during the season just ended (1910-1911), largely owing to the agitation in this country and the more strict supervision by foreign governments, and doubtless particularly to the natural fluctuation in the numbers of this pest abroad. These nests are, however, still coming in, some 100 nests being reported as received in New York State and 2 in Ohio. Reports have not been received from other states. The danger from this condition is perhaps even greater than when the nests are coming in more abundantly. The infrequent finding of these nests will naturally lead to a laxity of examination and result in an even greater risk of infested material being passed.

The Department's connection with the work is the same as before. The voluntary reports received from the customs officers and the railroad companies have been transmitted to inspection officials of the several states. These reports are by no means complete, and can not be complete under existing conditions.

The inspection notices sent to the Bureau of Entomology by the customs officials of the various ports of entry for the last fiscal year (July 1, 1910, to June 30,1911) indicate over 6,000 different shipments and some 90,000 separate parcels. This, however, includes bulbs, orchids, and greenhouse stock, as well as nursery stock proper. The 
total annual value of all plant importations in recent years has been a little over two million dollars, and the latest customs statistics available indicate that less than one fourth of this relates to nursery stock, namely, trees, shrubs, and ornamentals, including secdlings. Roughly, therefore, one fourth of the total number of shipments should be subject to careful examination. The standard trade in greenhouse materials and bulbs is subject to comparatively litile risk of introducing new dangerous pests.

One of the worst features of the situation is the importation by department and five-and-ten-cent stores of foreign ornamental nursery stock, which very often is not reported, and which state inspectors have the greatest difficulty in tracing. Nursery stock from abroad is also sent to this country to be sold under the hammer at various auctioneer establishments in large cities, and in both of these cases it is almost impossible to trace such stock or make any adequate inspection of it. In this city, such stock has been examined by agents of this Bureau under difficulty and without any real authority, and has in several instances been found infested with dangerous insects.

\section{FOREIGN IMPORTATIONS INTO THE DISTRICT OF COLUMBIA}

The conditions of commercial importations consigned to Washington either direct or in bond, and the current inspection work of the Bureau of Entomology relating to fruits, seeds, and plants imported by the Department of Agriculture, may be interesting as illustrating more pointedly the dangers which are common to the whole country.

Customs advices relating to 63 commercial importations to the District of Columbia have been received this year, and so far as possible these plants have been inspected. There is, however, no law for the District of Columbia which authorizes such inspection, and any examination made must necessarily be by the courtesy of the importers. This has sometimes been refused or is often grudgingly given, and at best has been without any special effort on the part of the importers to facilitate or promote thorough inspection. The worst feature of such imported stock is the masses of cheap ornamentals which are brought in and sold by department stores or under the hammer by auctioneers; and this condition applies to most of the other large cities of this country. In one instance of the present year an auction firm was courteous enough to allow the Department to destroy a large quantity of young spruce trees imported from Holland and which were badly infested with the spruce aphid, Lachnus juniperi Fab., an insect not known to occur in the United States. 
PLANT IMPORTATIONS BY THE U. S. DEPARTMENT OF AGRICULTURE

In the case of the importations of new stock, plants, or seeds by the Department of Agriculture, all such material coming to Washington is thoroughly inspected by officers of this Bureau, and if need be, disinfected or destroyed. Furthermore, all the lots of material which the Department prepares for distribution are again inspected and, if necessary, fumigated before being sent out. In this way, 750 different shipping orders have been inspected for the Bureau of Plant Industry, and many of these lots have been fumigated.

In the case of the importations by the Department of Agriculture this double inspection and fumigation, with usually a considerable period under quarantine, is believed to safeguard such material and to reduce to a minimum the likelihood of the introduction of new insect pests. As illustrating what may be brought in by such material and which in the case of private importers must often escape detection, it may be noted that more than 20 different pests have been intercepted on the importations by this Department, many of these new to this country, and with very unpleasant possibilities. These include such things as weevils infesting seeds, grasshoppers with wild grasses, grain insects, the mango seed weevil, a moth reared from mango seeds, scale insects, aleyrodid species (insects related to the white fly), a peach seed weevil from Siberia, Anthonomus druparium, already a very injurious pest in Europe, and if introduced into this country will probably be even more destructive than the plum curculio; a cecidomyiid (related to the Hessian fly) on Lotus introduced as a fodder plant; several scale insects; eggs of a leafhopper in cuttings of persimmon and peach from China. The latter, judging from its relationship to known pests, is capable of very great destruction to all sorts of orchard and ornamental trees. The eggs in this case are inserted under the bark, and to the ordinary observer would pass absolutely unnoticed.

The record of importations of new pests given above is the best possible argument for the passage of a national plant quarantine and inspection law.

\section{RECENTLY ESTABLISHED PESTS}

Perhaps the most destructive comparatively new insect pest is the alfalfa leaf weevil, which has already caused tremendous damage in Utah, and threatens to extend throughout the great alfalfa growing region of the middle West. It was evidently brought to this country from Europe on some imported goods, not improbably with the packing of nursery stock. 
Dr. J. B. Smith, of New Jersey, has called attention in his recent report (1910), p. 344, to the discovery of the European red taail (Dasychiria pudibunda L.) in New Jersey. The caterpillar of this moth is capable of being a very troublesome pest, and is somewhat related to the tussock moth. In Europe it is a general fecder and on the authority of Doctor Smith frequently entirely defoliates forest araas, and is there recognized as a first class pest, ranking with the gipsy and browntail moths. Its life habits are such that it is easily transported with nursery stock, and one of Doctor Smith's inspectors, in fact, found a cocoon from which an adult was bred, in stock imported from France during the winter of 1909-1910.

Mr. J. W. Chapman, of the entomological laboratory of the Bussey Institution, at Harvard University, has reported on the occurrence of the European smaller elm bark beetle (Scolytus muitistriatus), infesting in very large numbers the old historic elms of (ambridge, Mass. This insect works in company with the wood leoprard moth, and the two together have fairly well destroyed the magnificent elms in and surrounding the campus at Harvard Cniversity. 'The writer, this summer, witnessed the uprooting of the enormous moribund, or dead trunks, of these famous old trees, the cost merely of the removal of which was about $\$ 30$ per tree. Similar injury, charged to the leopard moth only, is reported by Britton and (ormie for the coastal region of Connecticut. [Bul. 169 (1911), Agr. Exp. Sta.] There seems to be no reason to doubt that this Scolytus is firmly established, and it looks very much as though these two insects together would be in the end almost as disastrous to elm in this country as the chestnut disease has been to the chestnut in the forests and parks of New York and adjacent states.

What bids fair to become a very important apple pest is the apple seed chalcis (Syntomaspis druparum.Boh.), which has been. made the subject of special study by Mr. C. R. Crosby, of the Entomological Department of Cornell Experiment Station (Bul. 265, April, 1909). This insect passes the winter in the larval stage in the apple seeds and can be very easily distributed by apples or apple seeds to all parts of the country. It is a well-known European pest and very likely came to this country with apple seeds imported from France, there being considerable import of such material for growth of seedling stock in this country. The investigations conducted by "the Bureau of Entomology in Pennsylvania last year have demonstrated that this insect has spread in destructive numbers into orchards in that state, and in some orchards at least one third of the crop was destroyed by it.

Among the newly established insect pests of subtropical fruits, perhaps the most important is Pulvinaria psidii, which is one of the 
worst pests in southeastern Asia on citrus and other subtropical plants. This insect has in recent years been introduced with nursery stock into Florida, and has already been widely distributed by one of the leading nursery firms of that state. It is now known to occur into several localities in Florida, and has been particularly damaging on fig trees at West Palm Beach, Miami, and some other points.

The Aleyrodes howardi, related to the white fly, has recently become established on the east coast of Florida, having been brought over on nursery stock from Cuba, where it seems to be a native.

The oriental scale pest (Conchaspis angraeci) has become established on figs at Miami and possibly elsewhere in Florida.

The mango seed weevil (Cyrptorhynchus mangifero) has come in very commonly in mango seeds imported for planting during the past ycar. A warning circular has been issued on this insect, and it is to be hoped that it has not escaped in Florida. Two important mango scale inscets have been brought in on shipments of trees to this country, and are still in existence in Florida, and it is doubtful whether they will be exterminated.

Mr. Woglum's eastern explorations during the past year, which have been so successful from the standpoint of the introduction of predaceous enemies and parasites, have fully demonstrated that the white fly is an introduced insect, its native home being the citrus region lying south of the Himalayan mountains, extending from India eastward across China. In this region, Mr. Woglum not only found the white fly commonly but also some of the fungous enemies of this insect, which are now established in Florida, and also control by parasitic and predaceous enemies.

The records above given sufficiently emphasize the risk which always attends foreign plant introductions, and particularly where such are new and come from regions which have been hitherto more or less commercially isolated.

\section{DANGEROUS FOREIGN DISEASES LIABLE TO BE IM- PORTED ON PLANTS}

By Dr. Perley Spaulding, Office of Forest Pathology, Bureau of Plant Industry, U. S. Department of Agriculture

This paper will deal very largely with but two diseases from which this country is in very immediate danger at present. These are the white pine blister rust and the potato wart disease. Besides these will be mentioned only tree diseases, as the speaker is more familiar with 